\title{
THE PLEA AGREEMENT - A NEW WAY OF NEGOTIATED JUSTICE IN THE EUROPEAN JUDICIARIES
}

\author{
L.A. LASCU
}

\section{Liviu-Alexandru LASCU}

Faculty of Law, Agora University of Oradea, Romania

Correspondence: Liviu-Alexandru Lascu, Agora University, 8 Piaţa Tineretului St., Oradea, Romania,

E-mail: liviu.lascu@univagora.ro

\section{ABSTRACT:}

The aim of this article is to emphasize the main features of the Plea Agreement procedure in the European traditional systems, common law and civil law, as well as the features of this concept as it has been implemented into the proceedings of some European countries and, accordingly, to analyse the reasons for which, the expertise of these already implemented procedures might be a pathway to solve many shortcomings of the national jurisdictions.

KEY WORDS: plea agreement, plea bargaining, guilty plea, negotiated justice, adhoc tribunals, adversarial, inquisitorial, common law, civil law.

\section{INTRODUCTORY REMARKS}

The Plea Agreement is a criminal proceeding arising from the Anglo - American judiciaries and consists in the fact that both the prosecutor and the Defense, taking into account the specific circumstances of the case, reach a mutually beneficial agreement. According to this agreement, the defendant accepts a self-incrimination while the prosecutor ensures a more convenient penalty than that the defendant would expect, if found guilty at the final judgment. Subsequently, this agreement must be approved by the court, thus relieving the judicial authorities to conducting adjudicative judgment according to the classical procedure. In such proceedings, in exchange for the defendant's admission of the alleged facts, depending on the jurisdiction to which we refer, the prosecutor have some different bargaining tools: he may waive some charges in exchange for the defendant's admission of committing others; he may offer a reduced penalty; he may offer lighter modes or less coercive forms of penalty enforcement; he can guarantee a range of benefits within the witness protection programs in exchange of the defendant's self incrimination and further cooperation for the prosecution of other criminals.

It is not completely random why this special procedure appeared in the criminal jurisprudence of the Common Law states, also known as the adversarial judicial systems. Here, the State, represented by the prosecutor, is only a part within the criminal process, sharing exactly the same statute like the defendant and the pattern of the process appears to be very similar to that of a civil process. In addition to this aspect, the adversarial systems traditionally provided significant procedural rights and safeguards for defendant while the 


\section{Liviu-Alexandru Lascu}

State did not employ professional criminal investigators until to a later stage ${ }^{1}$. So being, the evidentiary activity of the State representative was quite often difficult. In addition to that, unlike in the inquisitorial systems of the civil law countries (known also like the European continental countries) where the professional judges render the verdicts, in the adversarial systems they are traditionally done by a jury, whose predictability in decisions is extremely low. Given these circumstances, the need for compromise came naturally from the both parties, each of them trying to avoid a risk of an absolutely unfavourable decision rendered by the jury.

Plea Agreement procedures have not only evolved over the time in the AngloAmerican systems in as much as to become a common practice, especially in specific fields like organized crimes or corporate crimes, but due to the fact they significantly relieve the workload of the judicial bodies, began to be more and more attractive for the civil law systems applied in the European continental countries. In the past time, the latest systems were characterized by a clear disproportion between the Prosecutor and the Defense arms and also governed by the ubiquitous principle of mandatory prosecution ${ }^{2}$. So being, until not many years ago, they neither created concern for Prosecutor nor provided a legal possibility for negotiation with the defendant.

During the last decades of the twentieth century, the situation had been gradually changed when the majority of the European countries have amended the procedures in the aim of rebalancing the disproportion of the arms between the Prosecutor and the Defense by loaning some legal instruments from the adversarial systems. The fact many European states became members of the Council of Europe in the latest decades of the twentieth century and accordingly the effect of the European Convention for Human Rights on the national criminal legislations of those countries has determined, also, some significant changes in the sense of ensuring effective rights and safeguards for defendant during the criminal process and even of recommending a lenient conviction for the defendant who admit the facts as result of cooperation with the judicial bodies All the above mentioned circumstances have created a room for negotiating: firstly, because the increasing rights and safeguards of the defendant entailed a more and more difficult evidentiary activity for the Prosecutor, and secondly, because the increased Prosecutors' workload made the means of alternative resolution of the criminal cases more attractive than ever.

\section{CONTRASTING FEATURES OF THE PLEA AGREEMENT IN ANGLO- AMERICAN AND EUROPEAN CONTINENTAL MODELS}

Despite the fact most Anglo-American judicial systems don't use the same patterns of negotiated justice we can say that some common characteristics thereof distinguish them from those adopted in the European continental countries. These differences show us a pervasive presence of the negotiated justice in almost all kind of criminal cases and greater bargaining tools for the prosecutor in Anglo-American systems while a remaining reluctance in accepting the negotiation with the defendant in the European continental countries.

\footnotetext{
${ }^{1}$ See, G. Fisher, "Plea Bargaining's Triumph", Yale Law Journal (YLJ) 109, (2000), pp. 857-897

${ }^{2}$ See, for example, the German Code of Criminal Procedure, Section no. 152, paragraph (2): “Except as otherwise provided by law, the public prosecution office shall be obliged to take action in the case of all criminal offenses which may be prosecuted, provided there are sufficient factual indications", available on http://legislationline.org/download/action/download/id/3235/file/Germany_CC_1971_amended_2009_en.pdf
} 

EUROPEAN JUDICIARIES

The first different aspect is that related to the character of the defendant's act of selfincrimination. While in the Anglo-American countries this is deemed as a defendant's failure to invoke his/her affirmative defence or to raise his/her arguments in fighting the charges in exchange for the concessions offered by the prosecutor, in the Continental pattern, it supposes an in-court confession of the defendant. Thus, the Anglo-American agreement is deemed as a quasi-contract and the other like an informal gentlemen's agreement ${ }^{3}$. The aspect is not almost irrelevant because, while in the Anglo-American systems, the plea agreement is able to avoid a trial, the Continental pattern is only able to shorten the trial.

Another aspect is that of the field of application of this concept because within the Anglo-American systems there is no restriction of negotiated justice for all kind of crimes, regardless their gravity, while most of the Continental legislators still don't allow negotiations with the defendants who commit the gravest crimes. Moreover, if the former systems allow the negotiations to affect even the charges, in the sense of their alteration or partial elimination, the latest systems accept only some lenient penalties or less coercive ways of penalty enforcement to be negotiated with the defendant ${ }^{4}$.

When analysing the bargaining tools of the Prosecutor, we can see more potential of the Anglo-American prosecutor given by the system of formal qualification of the crimes in the Common Law countries. It creates the possibility to charge the defendant with many crimes for one single committed fact and, accordingly, to burden the defendant with a severe final sentence due to the system of arithmetic aggregation of the penalties issued for each charge. So being, the threat of a severe sentence for defendant makes a certain magnitude for the concession offered by the Prosecutor and even a greater availability toward negotiations for defendant. On the contrary, in the civil law countries, where the system of arithmetic aggregation of the penalties is not allowed and sentencing the defendant for many charges means, often, the penalty issued for the gravest charge and possibly an increase of it (taking in account the number and the gravity of the other charges), the room for negotiations is not very large. In addition to it, the prosecutor cannot waive charges and even more the gravest charge which attracts the most severe penalty.

Even though within the both systems, the court is required to approve the agreement between the prosecutor and the defendant, the involvement of the judge is different ${ }^{5}$. Within the Anglo-American version, it doesn't need any implication of the judge in the transaction and, accordingly, it doesn't entail any obligation excepting that of assessing the legality and proportionality of the agreement, while the judge in the Continental systems, once the agreement has been approved and accepted the in-court confession of the defendant, as a commitment arising from the deal, is bound to issue a reduced sentence according to the relevant law provision.

A final observation is on how much reliable are these agreements in these two systems, from the perspective of the defendant. While both judges are free to disregard the agreement, the problem is what will be the risk faced by the defendant if it even happens? As in the Anglo-American systems the agreement is deemed as a quasi-contract, if the prosecutor renounces on the deal or the judges disapproves of it, then the defendant will be free of

\footnotetext{
${ }^{3}$ See, M. Damaška, 'Negotiated Justice in International Criminal Courts', in Journal of International Criminal Justice (JICJ), 2 (2004), Oxford University Press, 2004, p. 1027.

${ }^{4}$ Ibidem, 1025

${ }^{5}$ Ibidem, 1026
} 


\section{Liviu-Alexandru Lascu}

revoking the plea. Consequently, the trial is going to proceed without any harm for defendant. Unlike, in the civil law countries, the plea agreement means an in-court confession and therefore, if the Prosecutor waives the deal or the judge disapproves it, the confession will remain valid and, very possible, a harsher than negotiated sentence will burden the defendant $^{6}$. Then, it is quite clear that the Anglo-American pattern is much more reliable than that of the civil law countries because in the former system, in the case of the agreement's breakdown, the out of court self-incrimination of the defendant does not affect its rights and safeguards during the trial.

Taking in consideration the above mentioned differences, plus other less significant, of the concept of plea agreement in these two judicial systems, we can conclude the AngloAmerican model is better developed, widely practiced in all kind of criminal cases, offers a greater potential in negotiations for the Prosecutor and is, also, more reliable for the defendant. Moreover, the mutual concessions of the parties do not entail any involvement and obligation for the judge, thus not affecting his/her neutrality. Thus, the perspective of the agreement's failure does not affect the defendant rights and safeguards during the trial due to the followings: the out of court self-incrimination can be revoked; it has no any evidentiary weight in the trial; it is not known by the jury; the judge remains neutral in relation to the agreement.

In the Continental systems, plea agreement is just a pioneering procedure, allowed only in the cases dealing with less grave offences, without prejudice to the charges, and involving an in-court confession which remains valid evidence, even when the agreement is violated by the prosecutor or disapproved by the judge.

However, despite of the features showing it as a better model in achieving an alternative resolution of the criminal cases, the Anglo-American plea agreement is not far away from criticism. The first is related to the asymmetrical position of the negotiating parts, that is, the severity of the threatened penalties as well as the greater informational and financial possibilities of the Prosecutor during the trial and even the psychological imbalance between the parties, might lead to some undesirable situations in which, even some innocent defendants would prefer an agreement with the prosecutor instead of an unpredictable verdict at the end of the trial ${ }^{7}$. This tactic of the prosecutor deliberately exaggerating the number and the gravity of the charges in order to create a larger room for negotiations entails a lot of criticism especially in U.S.A.. In order to prohibit such practice in U.K., the Code for the Crown Prosecutors, explicitly provides some rules in this respect ${ }^{8}$.

\footnotetext{
${ }^{6}$ Ibidem, 1027

${ }^{7}$ See M. Yant 'Presumed Guilty: When Innocent People Are Wrongly Convicted' (1991), Prometheus Books, New York, p. 172

${ }^{8}$ See, Code for the Crown Prosecutors, Selection of charges:

6.1 Prosecutors should select charges which: a. reflect the seriousness and extent of the offending supported by the evidence; $b$. give the court adequate powers to sentence and impose appropriate post-conviction orders; $c$. enable the case to be presented in a clear and simple way.

6.2 This means that prosecutors may not always choose or continue with the most serious charge where there is a choice.

6.3 Prosecutors should never go ahead with more charges than are necessary just to encourage a defendant to plead guilty to a few. In the same way, they should never go ahead with a more serious charge just to encourage a defendant to plead guilty to a less serious one.

6.4 Prosecutors should not change the charge simply because of the decision made by the court or the defendant about where the case will be heard.

6.5 Prosecutors must take account of any relevant change in circumstances as the case progresses after charge. Available on http://www.cps.gov.uk/publications/code_for_crown_prosecutors/charges.html
} 
Some other specialists criticize this marked -oriented approach of the plea agreement because it means an inter-party arrangement whose outcome might negatively affect the interest of the victims and of the general public in what regarding the transparency of criminal justice ${ }^{9}$. The lenient penalties offered by the prosecutor might, also, create a public sense of injustice. No less important is the discretionary power of initiating and concluding agreements of the prosecutor which might lead to an unequal treatment for those defendants for whom, the prosecutor doesn't have any interest in concluding an agreement with.

Finally, the power to negotiate justice and the bargaining tools to the prosecutor's disposal raise a problematic issue of its role in the administration of criminal justice. In the Common Law jurisdictions, the judge is traditionally deemed as the best positioned in achieving the public interest in criminal matters. However, the out of court inter-party agreements which exclude the judge from attributing criminal responsibility and imposing penalties and the increased case-law of this procedure show a shift of the Prosecutor into the most important decision-maker and also make questionable this traditional role of the judge in doing justice in criminal matters ${ }^{10}$.

Undoubtedly, the above mentioned are not necessarily systemic weaknesses of the plea agreement procedure in the Anglo-American systems but rather found on a case by case basis, however, the fact there are several opinions of the experts depicting these weaknesses, demonstrates this procedure is not infallible but rather can elicit improvements.

\section{PLEA AGREEMENT IN THE PROCEEDINGS OF THE CIVIL LAW JURISDICTIONS}

As said in the above chapters, while the Anglo-American systems have already developed a solid and thorough practice in applying the Plea Agreement procedure, especially in U.S.A. ${ }^{11}$ where the greatest majority of the cases are solved in this way, in the European Continental countries, the practice shows us a remaining reluctance for implementing it in many countries as well as some problematic issues in the countries where Plea Agreement has been adopted. In this chapter we propose a brief comparative analysis of these issues and have chosen seven representative countries but not only that adopted or accepted Plea Agreements within their jurisprudence from each European Continental category, that is, France, Italy and Germany from the group of the West European countries, Poland and Romania from the Central and East European countries, Estonia and Georgia belonging to the group of the exsoviet countries.

\subsection{France}

In France, the Plea Agreement with the name La comparution sur reconnaissance préalable de culpabilité (CRPC), also called plaider coupable has been introduced in the French Criminal Procedure Code by the so called "Perben Act II" of 9 March 2004, which was designed to adapt the French criminal justice to the evolution of criminality. The pleabargaining procedure, previewed within Articles 495-7, 495-16 and 520-1 of the French Criminal Procedure Code is a new response to those situations in which, according to the concrete circumstances and the spirit of the criminal legislation, a fully adjudicative trial can

\footnotetext{
${ }^{9}$ See, M. Damaška, supra note 3, p. 1028

${ }^{10}$ See, F. Tulkens, 'Negotiated Justice', in M. Delmas-Marty, J.R. Spenser, European Criminal Procedures, Cambridge University Press, Cambridge (2002), p. 74

${ }^{11}$ See, A. Alschuler, W. 'Plea Bargaining and Its History' in Colombia Law Review 79 (1), (1979) pp. 1-43
} 


\section{Liviu-Alexandru Lascu}

be avoided. According to the above-mentioned articles, the prosecutor could make a deal with the defendant who is suspect of committing some relatively minor crimes ${ }^{12}$ by proposing a penalty not exceeding one year in prison in turn for the defendant's guilty plea. Once concluded, the deal is a subject of the approval of the president of the tribunal de grande instance (High Court) or of another judge appointed for the former. According to the provisions of the Article 495-11, the defendant, assisted by his/her attorney, after concluding the agreement with the prosecutor, has to do an in-court confession of his guilt. The judge, according to the concrete situation and taking in account the supporting evidence of the case, can render an ordinance of confirming the penalty proposed by the prosecutor which has the power of a final sentence. The judge's ordinance must be enforced immediately after its pronouncement.

This new procedure is not very well viewed by the French practitioners. Most of them consider it as creating the premises for the violation of defendants' rights and safeguards because it gives too much power to the prosecutor and would encourage defendants to accept a sentence only in order to avoid the risk of a more severe sentence in a trial, even if they did not really deserve it. A relevant proof of its lack of popularity in France is the statistic of criminal cases in $2011^{13}$ which shows 77,569 criminal cases out of 513,911, representing only $15,09 \%$ of the decisions rendered by the correctional courts, were concluded following a Plea Agreement.

\subsection{Italy}

Italy was a pioneer of the European Continental countries implementing the Plea Agreement, called patteggiamento ${ }^{14}$, as it is known among the Italian provisions of criminal procedure since 16 February 1987 when the Article 45 point 2 of the Law no. 81, enabling legislative delegation to the Government of the Republic for promulgation of the new Code of Criminal Procedure entered into force and as it was reshaped in the Article 444 of the Italian Code of Criminal Procedure as amended by the Law no. 134 of June 12 2003. Summarizing its content, we can see an opportunity for the defendant to conclude an agreement with the prosecutor when he/she deems that the punishment that would, concretely, be handed down is less than five years imprisonment. In turn for his/her guilty plea, the prosecutor may offer a reduced sentence, an exempt from the payment of the proceeding's fees, a drop of some charges or a change of them with other less severe. Basically, the Italian bargaining is not about the charges but about the sentence in the sense, once concluded and approved, the penalty can be reduced by one third. The deal between the prosecutor and the defendant must be submitted to the Court. The judge is not bound to this deal and after assessing the evidentiary support of the Plea Agreement, he/she can disapprove it, if the evidence shows the defendant's guilt is not sufficiently proved, or in the case, if proved to be guilty, the proposed punishment for defendant is too lenient. If the defendant is deemed guilty and there is

\footnotetext{
${ }^{12}$ At the moment of its adoption in 2004, the Article 495-7 of the French Criminal Procedure Code provided a limit of punishment of 5 years imprisonment for the crimes which could be a subject of plea agreement. The Article 495-7 has been amended on 13 December 2011 and the limit of punishment has been removed excepting the cases of intentional or unintentional, physical or sexual assault for which, some limits of punishments still remained.

${ }^{13}$ See, 'Les chiffres clés de la Justice - 2012', Ministère de la Justice, Secrétariat general, Service support et moyens du ministère sous-direction de la Statistique et des Études 13, place Vendôme - 75042 Paris Cedex 01, available on http://www.justice.gouv.fr/art_pix/chiffres_cles_2012_20121108.pdf

${ }^{14}$ See, Borasi, Ivan, Il patteggiamento. Approcio di sistema alle implicazioni procesuali, Altalex Editore, Ebook format, chapters I-II
} 


\section{EUROPEAN JUDICIARIES}

proportionality between the committed facts and the proposed punishment, the judge must approve the agreement. The Italian rules of criminal proceedings provide the possibility for this sentence of approval the plea agreement to be appealed before the Corte di Cassazione (Court of Cassation), the highest Italian court which rules only on assessing the legality of procedure and the interpretation of the law.

Even though the Italian practitioners have much more expertise than other European colleagues in negotiating justice and even a reshaping of the relevant law provision according to the practice requirements, they still consider this procedure as very difficult to reconcile with the Italian traditional procedural institutions. A conclusive opinion on this matter is done by the Italian highest court, Corte di Cassazione in its sentence 15 Cassazione Penale (1990) 47 , in which, the negotiated admission of guilt was deemed as a 'hypothetical judgment ${ }^{15}$.

\subsection{Germany}

The German approach to doing negotiated justice was the most original among the European Continental countries because, in spite of its obvious presence in the practice, there was no legal provision providing expressly a Plea Agreement procedure since May 2009 when the German Federal Parliament adopted a new provision of the German Criminal Procedure Code, Section 257 c named Negotiated Agreement which explicitly acknowledged plea bargaining. Until then, the so called Absprachen (The Agreements) emerged in practice without statutory authorization and, paradoxically, not being bound by some legal limits of the penalties to the offenses on which the plea guilty was negotiated, such agreements could be encountered in many kinds of criminal cases, even in those involving serious crimes like drug trafficking and homicide. This is an aspect which demonstrates a less concern of the practitioners in harmonizing their work with the procedural principles but rather in achieving their main goals. Due to the fact that until the explicit adoption of plea agreement in the German Criminal Procedure Code a practice in this respect has been already outlined, the law provision did nothing more than to legislate something which became almost usual. In this respect, it worth mentioning some characteristics of the German Negotiated Agreement, as previewed in the Section $257 \mathrm{c}$ : there is no provision limiting the application of plea agreement to only some kind of offenses or to the offenses with a specific limit of penalty previewed by the law; an in-court confession shall be an integral part of any negotiated agreement; the measures of reform and prevention, may not be the subject of negotiation; on free evaluation of all the circumstances of the case as well as general sentencing considerations, the court may indicate an upper or lower sentence limit and the agreement will come into existence only if both the prosecutor and the defendant agree with the sentence limit proposed by the court; if legal or factually significant circumstances have been overlooked in the agreement, the court is not bound of it and may enter a trial following the classic procedural rules and then the defendant's confession may not be used, a fact the court shall notify to the parties.

As a conclusion, we must remember the former German approach because of its originality and ingenuity to find a way of doing negotiated justice by interpreting the criminal procedure in the sense that something which is not expressly prohibited may be permitted as well as the current formula which does not limit its application only to some less serious crimes and which protects the defendant's right of not self-incriminating, in the case the

\footnotetext{
${ }^{15}$ See, G. Lattanzi, E. Lupo, ‘Codice di Procedura Penale’, Vol. VI, Giuffré, Milano, 1997, p. 205-215.
} 


\section{Liviu-Alexandru Lascu}

agreement fails. However, due to the fact that Plea Agreement has some inaccuracies with the traditional principles of criminal procedures it is not very popular with the German specialists ${ }^{16}$.

\subsection{Poland}

Since 1998, Poland has also had a kind of plea agreement ${ }^{17}$ which proved to be a very original one because according to the Article 387 paragraph 1 of the Criminal Procedure Code of Poland, the agreement is not concluded in the pre-trial phase of the process but during the hearings before the court. The plea agreement is applicable only to the misdemeanours punishable by no more than 8 years of imprisonment. The procedure allows the defendant, until the conclusion of the first examination at the first-instance hearing, to submit a motion for a decision convicting him and sentencing him to a specified penalty or penal measure without evidentiary proceedings. It is called also the procedure of 'voluntary submission to a penalty' and allows the court to pass the agreed sentence without reviewing the evidence. The proposed penalty will be accepted by the court and afterward enforced only if the prosecutor, the victim and the court, all of them, agree on it. Nevertheless, the court may not accept the terms of proposed plea agreement, in spite of the fact they were already agreed by the victim and the prosecutor and may suggest some changes. If the defendant agrees with the court requirements and submits a new penalty proposition accordingly, the court must approve it and render the sentence according to the plea agreement. Even if the Polish Plea Agreement supposes an all parties deal during the trial and apparently, there is no reason for appealing the sentence, all of them, the prosecutor, the defendant and the victim have, also, the right to appeal. We can mention, as a very interesting feature of this procedure, the key role that has been assigned to the victim because he/she appears as a veritable 'auxiliary prosecutor'. Is well known the fact in Polish criminal proceedings the victim can ask and may act as an 'auxiliary prosecutor' and therefore, among the other similar procedural rights, the victim gains also the right to appeal, exactly like the official prosecutor. Finally, if the Plea Agreement represents, among the others, a concession to the defendant in exchange for his/her conduct, in the sake of the fairness of the justice act, the increased role of the victim within the Plea Agreement procedure appears as being welcomed.

\subsection{Romania}

The new Code of Criminal Procedure of Romania into force since February 1, 2014 explicitly previews the procedure of plea agreement ${ }^{18}$. According to it, during the pre-trial phase of the criminal process, from the incentive of both the defendant and the prosecutor, can be concluded an agreement of defendant's admission his/her guilt for the charges, or only for part of them, in exchange for a lenient punishment. In Romania, the bargain is not about the charges but only about the sentence that is, a reduced penalty or less coercive forms of

\footnotetext{
16 See, B. Schüneman, 'Wohin treibt der deutsche Strafprozess' in Zeitschrift für die gesamte Strafrechtswissenschaft, 114 (2002), p. 570. Paradoxically, in spite of the fact the author Bernard Schüneman is one of the most bitter opponent of introducing plea agreement into the German legislation, he had to admit in his research that 91 per cent of the judges, 90 per cent of the prosecutors, and 53 per cent of the defence lawyers expressed a preference for informal agreements rather than trial in cases involving evidential difficulty.

${ }^{17}$ See, the Criminal Procedure Code of Poland, Act of 6 June 1997, Article 387 para. 1-5, (English version) available on http://legislationline.org/download/action/download/id/4172/file/Polish\% 20CPC\%201997am\% 202003 en.pdf

${ }^{18}$ See, the new Criminal Procedure Code of Romania as adopted by the Law no.135/2010, published in the Official Monitor of Romania no. 486 of July 15, 2010 and modified by the Law no. 255/2013 published in the Official Monitor of Romania no. 515 of August 14, 2013, Articles 478-488.
} 


\section{EUROPEAN JUDICIARIES}

penalty enforcement like, for example, the suspending of its enforcement. The written consent of the supervisory prosecutor is necessary as a precondition to conclude the plea agreement. According to the law provision, concluding such agreement is prohibited for the most serious crimes for which the criminal law previews a punishment of more than seven years imprisonment. In order of guaranteeing the legality and the interest of the defendant within negotiations, the law previews as a binding rule, the defendant to be assisted by an attorney. The plea agreement in its written form and accompanied by evidentiary support is submitted to the court of first instance. The judge, once receiving it, commences a public but noncontradictory session in which invite the prosecutor, the defendant and his/her attorney to make opening speeches. After the hearings and examination of the evidentiary support of plea agreement, the court takes a decision which can be: a sentence of convicting the defendant to a punishment no more severe than that proposed in the agreement, if the legality of proceedings, the rights of defendant and the proportionality between the gravity of the facts and the severity of the penalty are provided; a disapproval of the plea agreement and the return of the criminal file to the Prosecutor's Office if there is not enough evidentiary support for demonstrating the guilt of the defendant, the agreement overlooked some legal requirements or, the proposed penalty is too much lenient in comparison with the committed facts. Whatever of the both above mentioned decisions of the court of first instance would be rendered, the defendant and the prosecutor can appeal it.

In this moment is too early to assess the impact of Plea Agreement in the criminal jurisprudence of Romania but some remarks related only to its legal background can be done. It appears to be in the trend of European Continental model, applied only for some less severe crimes, with scarce bargaining tools for the prosecutor and involving an in-court confession of the defendant.

\subsection{Estonia}

Since 1 September 2011 when the amendments of the Criminal Procedure Code adopted on 23 February 2011 entered into force, Estonia has its own Plea Agreement ${ }^{19}$ which is actually called Alternative Proceedings (Articles 233-238). It supposes a request of the defendant to the Prosecutor's Office to follow this procedure, according to which the court may adjudicate a criminal matter by way of alternative proceedings on the basis of the materials of the criminal file without summoning the witnesses or other qualified persons. Alternative Proceedings is prohibited for the most serious crimes for which the punishment of life detention is previewed, as well as for the cases where several defendants are accused and at least one of them does not consent to the application of alternative proceedings. If the defendant and the prosecutor consent to the application of alternative proceedings, the Prosecutor's Office prepares the statement of charges which is going to be included in the criminal file and the file shall be sent to the court.

Once the criminal file was received and the session was opened, the judge announces the commencement of examination by the court and makes a proposal to the prosecutor to make an opening speech. The prosecutor gives an overview of the charges and the evidence which corroborates the charges and which the prosecutor requests to be examined by the court. After assessing the legality of the proceedings, the judge shall ask whether the

\footnotetext{
${ }^{19}$ See, the Criminal Procedure Code of Estonia, passed on 12.02.2003 published in the Riigi Teataja I 2003, 27, 166 entered into force on 01.07.2004, Articles 233- 238, (English version) available on http://legislationline .org/download/action/download/id/4709/file/Estonia_CPC_am2013_en.pdf
} 


\section{Liviu-Alexandru Lascu}

defendant understands the charges, whether he/she confesses to the charges and whether he/she consents to the adjudication of the criminal matter by way of alternative proceedings. If all the necessary conditions are fulfilled, the judge commences the hearings and the participants in the court session shall rely only on the materials of the criminal file. If a judgment of conviction is made by way of alternative proceedings, the court shall reduce the principal punishment to be imposed on the accused by one-third after considering all the facts relating to the criminal offence.

A short comment on this Estonian Alternative Proceedings is the fact that the bargaining tools of the prosecutor are very scarce. He/she cannot propose a kind or a limit of penalty as long as the law previews a reduction of one-third of the punishment and this is to the disposal of the judge. This procedure does not follow a pattern of Plea Agreement in its European Continental variant but rather it is a variant of the guilty plea proceedings which commences during the Pre-Trial phase of the process.

\subsection{Georgia}

The Plea Agreement was introduced in Georgia in 2004 and despite its statute of exsoviet country, until then under a strong influence of the civil law system, basically the new adopted Georgian plea bargaining, in most respects, is inspired by the Anglo-American models ${ }^{20}$. It consists of an alternative and consensual way of criminal case settlement without an in-court confession of the defendant who agrees to plead guilty in exchange for a lesser charge or for a more lenient sentence or, according to the case, for dismissal of certain related charges (Article 209 of the Criminal Procedure Code of Georgia). The Georgian procedure is based on the principle of the free choice of the defendant, equality of the parties and protection of his/her rights and safeguards. The defendant has the right to reject the plea agreement at any stage of the criminal proceedings before the court renders the judgment and the use in the future of the information provided by the defendant under the plea agreement against him is explicitly prohibited. In concluding the agreement, the prosecutor is obliged to take into consideration the public interest, the severity of the penalty, and the personal characteristics of the defendant and as a guarantee of these aspects, the procedure previews the consent of the supervisory prosecutor as necessary precondition to conclude plea agreement and to amend its provisions. The court is not bound by the agreement and if the presented evidence is not sufficient to support the charges or if other requirements stipulated by the Criminal Procedure Code of Georgia are violated by the agreement, the judge can return the case to the prosecution, not before offering to the parties the possibility to change the terms of the agreement. If the court satisfies itself that the defendant fully acknowledges the consequences of the plea agreement, he/she was represented by the Defence council, his/her will is expressed in full compliance with the legislative requirements without deception and coercion, also if there is enough body of doubtless evidence for the conviction and the agreement is reached on legitimate sentence - the court approves the plea agreement and renders guilty judgment. If any of the abovementioned requirements are not satisfied, the court rejects to approve the plea agreement and returns the case to the prosecutor. Another important aspect which deserves to be mentioned is the position of the victim in relation to the plea agreement. Under Article 217 of the Criminal Procedure Code of Georgia, the prosecutor

\footnotetext{
${ }^{20}$ See, Alkon, C, 'Plea Bargaining as a Legal Transplant: A Good Idea for Troubled Criminal Justice Systems?' in Transnational Law \& Contemporary Problems, a Journal of University of Iowa College of Law, vol. 19, Spring 2010, 363-369
} 


\section{EUROPEAN JUDICIARIES}

is obliged to consult with the victim prior to concluding the plea agreement and to inform him/her about this and is, also, obliged to take into consideration the interests of the victim and as a binding rule, to conclude the plea agreement only after the damage is already compensated.

As a conclusion, we can see a very unusual and courageous legislative action from the Georgian legislator when adopting this procedure in very relative terms with the Anglo/American Plea Agreement, in spite of the judicial tradition inspired by the civil law systems and the lack of adversarial expertise in the Georgian criminal jurisprudence.

\section{FINAL REMARKS}

Taken from the Common Law legal systems, the Plea Agreement procedure began to be implemented in the European continental judiciaries, especially in the last decade and it succeeded to be already a common practice within these countries. Even if the models adopted in these above mentioned judiciaries differ from those implemented in the AngloAmerican systems, that is, a weak implementation, only in minor criminal cases and not just to avoid the trial but actually to shorten it, most likely, in the future, after the assessment of its application in practice proves to be a positive one, for sure, this procedure will be expanded to the cases involving serious crimes and the limits of negotiating will be allowed to a wider range. So far, the issue of justice negotiation is inconsistent with certain traditional principles and institutions of the criminal proceedings in the civil law countries and is still hard to be accepted for some specialists.

\section{BIBLIOGRAPHY}

See, G. Fisher, "Plea Bargaining's Triumph”, Yale Law Journal (YLJ) 109, (2000),

See, for example, the German Code of Criminal Procedure, Section no. 152, paragraph (2): "Except as otherwise provided by law, the public prosecution office shall be obliged to take action in the case of all criminal offenses which may be prosecuted, provided there are sufficient factual indications", available on http://legislationline.org/download/action/download/id/3235/file/Germany_CC_1971_amende d_2009_en.pdf

See, M. Damaška, 'Negotiated Justice in International Criminal Courts', in Journal of International Criminal Justice (JICJ), 2 (2004), Oxford University Press, 2004,

See M. Yant 'Presumed Guilty: When Innocent People Are Wrongly Convicted' (1991), Prometheus Books, New York,

See, Code for the Crown Prosecutors, Selection of charges:

6.1 Prosecutors should select charges which: a. reflect the seriousness and extent of the offending supported by the evidence; $b$. give the court adequate powers to sentence and impose appropriate post-conviction orders; $c$. enable the case to be presented in a clear and simple way.

6.2 This means that prosecutors may not always choose or continue with the most serious charge where there is a choice.

6.3 Prosecutors should never go ahead with more charges than are necessary just to encourage a defendant to plead guilty to a few. In the same way, they should never go ahead with a more serious charge just to encourage a defendant to plead guilty to a less serious one. 6.4 Prosecutors should not change the charge simply because of the decision made by the court or the defendant about where the case will be heard.

6.5 Prosecutors must take account of any relevant change in circumstances as the case $\begin{array}{lccc}\text { progresses } & \text { after } & \text { charge. Available } \\ \text { http://www.cps.gov.uk/publications/code_for_crown_prosecutors/charges.html }\end{array}$

See, M. Damaška, supra note 3, 


\section{Liviu-Alexandru Lascu}

See, F. Tulkens, 'Negotiated Justice', in M. Delmas-Marty, J.R. Spenser, European Criminal Procedures, Cambridge University Press, Cambridge (2002),

See, A. Alschuler, W. 'Plea Bargaining and Its History' in Colombia Law Review 79 (1), (1979)

At the moment of its adoption in 2004, the Article 495-7 of the French Criminal Procedure Code provided a limit of punishment of 5 years imprisonment for the crimes which could be a subject of plea agreement. The Article 495-7 has been amended on 13 December 2011 and the limit of punishment has been removed excepting the cases of intentional or unintentional, physical or sexual assault for which, some limits of punishments still remained.

See, 'Les chiffres clés de la Justice - 2012', Ministère de la Justice, Secrétariat general, Service support et moyens du ministère sous-direction de la Statistique et des Études 13, place Vendôme - 75042 Paris Cedex 01, available on http://www.justice.gouv.fr/art_pix/chiffres_cles_2012_20121108.pdf

See, Borasi, Ivan, Il patteggiamento. Approcio di sistema alle implicazioni procesuali, Altalex Editore, Ebook format, chapters I-II

See, G. Lattanzi, E. Lupo, 'Codice di Procedura Penale', Vol. VI, Giuffré, Milano, 1997, See, B. Schüneman, 'Wohin treibt der deutsche Strafprozess' in Zeitschrift für die gesamte Strafrechtswissenschaft, 114 (2002), p. 570. Paradoxically, in spite of the fact the author Bernard Schüneman is one of the most bitter opponent of introducing plea agreement into the German legislation, he had to admit in his research that 91 per cent of the judges, 90 per cent of the prosecutors, and 53 per cent of the defence lawyers expressed a preference for informal agreements rather than trial in cases involving evidential difficulty.

See, the Criminal Procedure Code of Poland, Act of 6 June 1997, Article 387 para. 1-5, (English version) available on http://legislationline.org/download/action/download/id/4172/file/Polish\% 20CPC\%201997am\% 202003 en.pdf

See, the new Criminal Procedure Code of Romania as adopted by the Law no.135/2010, published in the Official Monitor of Romania no. 486 of July 15, 2010 and modified by the Law no. 255/2013 published in the Official Monitor of Romania no. 515 of August 14, 2013, Articles 478-488.

See, the Criminal Procedure Code of Estonia, passed on 12.02.2003 published in the Riigi Teataja I 2003, 27, 166 entered into force on 01.07.2004, Articles 233- 238, (English version) available on http://legislationline .org/download/action/ download/id/4709/file /Estonia_CPC_am2013_en.pdf

See, Alkon, C, 'Plea Bargaining as a Legal Transplant: A Good Idea for Troubled Criminal Justice Systems?' in Transnational Law \& Contemporary Problems, a Journal of University of Iowa College of Law, vol. 19, Spring 2010. 